\title{
Effects of selected groundwater chemical traits on a salt marsh community
}

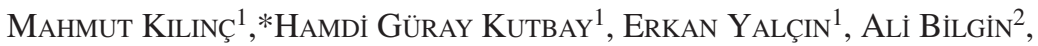 \\ Kenan Aver ${ }^{3}$, Solmaz Gencoglu Topaloglu ${ }^{3}$ \\ ${ }^{1}$ University of Ondokuz, Mayis Faculty of Arts - Sciences, Department of Biology, \\ 55139 Kurupelit-Samsun, Turkey \\ ${ }^{2}$ Rize University, Faculty of Arts - Sciences, Department of Biology, 53100 Rize, Turkey \\ ${ }^{3}$ Ministry of Agriculture and Rural Affairs, Soil and Water Resources Research Insti- \\ tute, Samsun, Turkey
}

Electrical conductivity, exchangeable sodium ratio and water depth have negative impacts, whereas soil organic matter concentration has a positive impact on Black Sea salt marsh vegetation. The most saline soils were characterized by Salicornia prostrata vegetation and associated with exchangeable sodium ratio. Alhagi pseudalhagi and Tamarix smrynensis populations were associated with water depth, while Juncus littoralis, Ammophila arenaria and E. paralias were associated with soil organic matter. Euphorbia paralias, Ammophila arenaria and Iris orientalis were associated with acidity.

Key words: Black Sea, groundwater, salt marsh, vegetation, Black Sea

\section{Introduction}

Salt marsh ecosystems are known to be a highly structured environment providing a gradient of environmental conditions from extremely inundated and saline to relatively mesic (ZHANG 1996, CANTERO et al. 1998a). Coastal salt marshes vegetated by herbs, grasses, and low shrubs bordering saline water bodies are unique ecosystems universally recognized for their exceptional ecological value (MiTsch and GosselinK 1993). They comprise areas of land bordering the sea largely covered with vegetation and subject to periodic tidal inundation (KENNISH 2001). A small number of halophytic species that are spatially segregated in pronounced vegetation zones dominate these ecosystems (BERTNESS et al. 1992, Asri and GHorbanli 1997, AbD El-Ghani 2000a, Apaydin et al. 2009). The use of halophytes as indicators of groundwater and soil chemical traits could be an effective and useful method for scientists to inform extension agents, and end users about the state of the environment (Li Wei-Quiang et al. 2008, Shaltout and Al-Sodany 2008).

\footnotetext{
* Corresponding author, e-mail: hguray@omu.edu.tr

Copyright $^{\circledR} 2011$ by Acta Botanica Croatica, the Faculty of Science, University of Zagreb. All rights reserved.
} 
It has been reported that vegetation zonation in salt marshes is primarily related to the salinity of the groundwater (CHAPMAN 1974, ABDEL-RAZIK and ISMAIL 1990, PENNINGS and Callaway 1992, Jongman et al. 1995, Cantero et al. 1998a, Kutbay and Demir 2001) and groundwater chemical traits are often considered to determine the possibility of restoring or rehabilitating a salt marsh.

This study is aimed to determine the role of chemical traits of groundwater on plant communities in a salt marsh located in the north of Turkey using numerical methods. For this reason, selected groundwater and soil chemical traits were used and the roles of these traits on plant communities in the study area were evaluated.

\section{Study area}

The study area is situated on the east bank of the Kiz1lırmak River in the northern and northeastern parts of Bafra town (41 $\left.43^{\prime} 10.09^{\prime \prime} \mathrm{N}, 35^{\circ} 59^{\prime} 26.32^{\prime \prime} \mathrm{E}\right)$, North Turkey, in the Central Black Sea Region (Fig. 1). The area is characterised by a semi-humid Mediterranean climate with the highest potential evaporation rate $(140 \mathrm{~mm})$ occurring during June (ENGIN and KORKMAZ 1990, APAYDIN et al. 2009).

The study area is located at Kizılırmak River delta. The Kizılırmak River delta is an exception in that coastal erosion is an environmental threat that increases inundation, thus leading to land loss. Coastal retreat in the study area is between 2.5-5.0 m per year. The sediments supplied by the Kizllırmak River feed the coastal barriers in the study area under the influence of the longshore flows with an average speed of $40-50 \mathrm{~cm} \mathrm{~s}^{-1}$. The soils of the study area are formed from alluvial materials. The sediments in the area consist of Upper Pleistocene and Holocene alluviums and vary from fine sand, silt and clay in varying thickness and extents. The thickness of Quaternary deposits increases northwards. The soils are

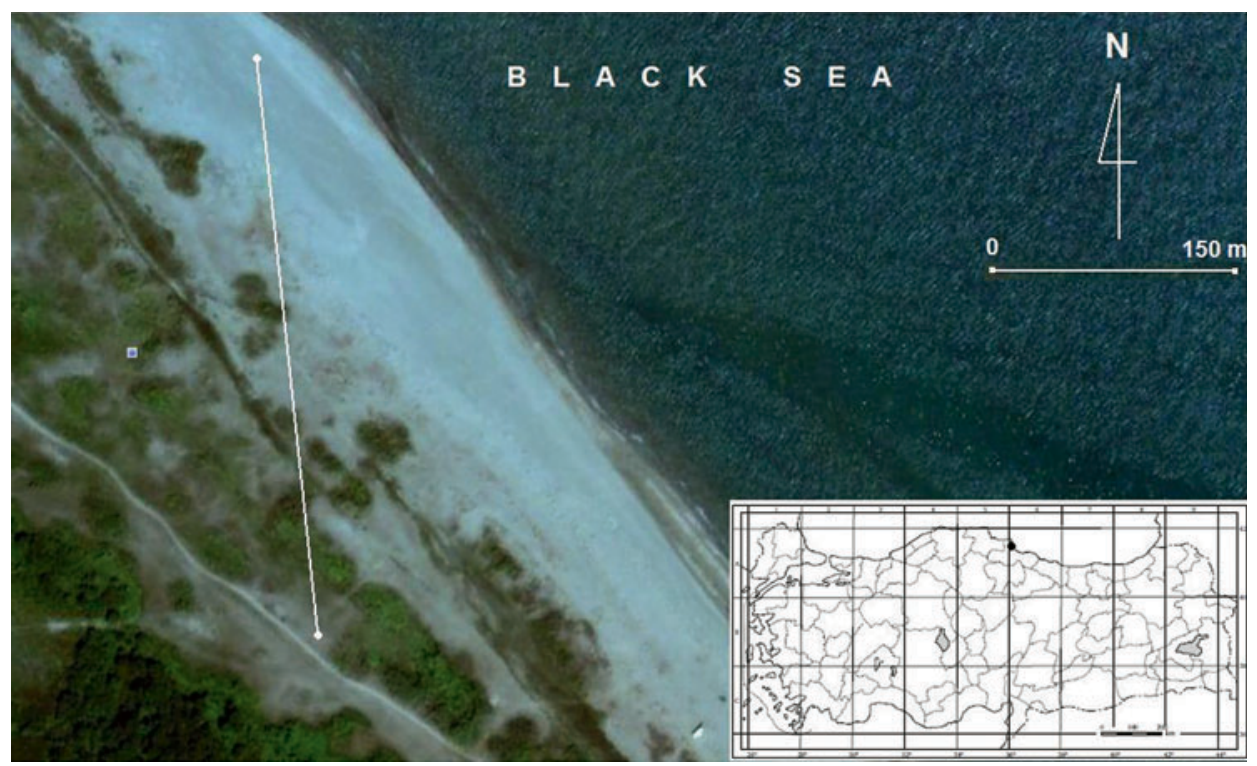

Fig. 1. Map of the study area 
fine-textured with moderate hydraulic conductivity. Sublayers of these soils are massive in structure (AlPAR 2009, DEMIR et al. 2009). Soil pH and electrical conductivity are rather high and soils are alkaline (ARSLAN et al. 2007). Additionally, groundwater in the study area has high electrical conductivity (DEMIR et al. 2009).

Coastal dunes occur along the shoreline and they extend about $30-40 \mathrm{~m}$ from the shoreline and coastal dunes are characterised by Ammophila arenaria subsp. arundinacea, Euphorbia paralias and Tamarix smrynensis communities. Coastal sand dunes are replaced by salt pans and these salt pans are characterised by Salicornia prostrata communities. At the edge of these communities Alhagi pseudalhagi communities occur. About 200 $\mathrm{m}$ from the shoreline Juncus littoralis C. A. Meyer and Juncus acutus communities occur. About $270 \mathrm{~m}$ from the shoreline inland dunes are characterised by Iris orientalis Miller communities (Fig. 2).

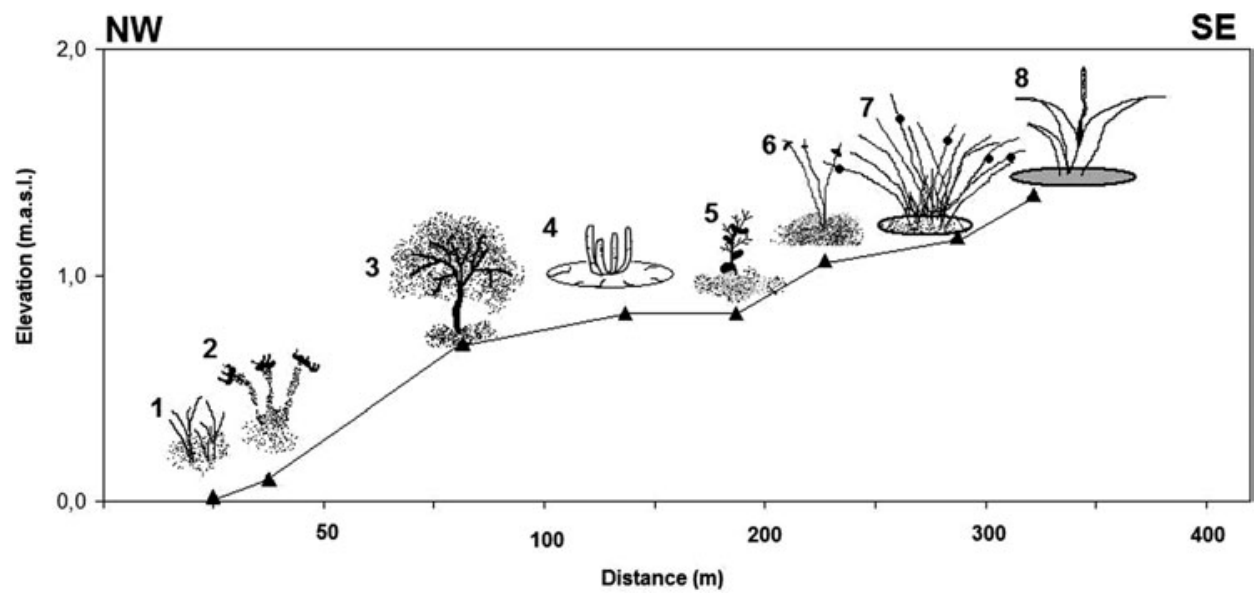

Fig. 2. The transect showing plant zonation in the study area. 1. Ammophila arenaria, 2. Euphorbia paralias, 3. Tamarix smrynensis, 4. Salicornia prostrata subsp. prostrata, 5. Alhagi pseudalhagi, 6. Juncus littoralis, 7. Juncus acutus, 8. Iris orientalis

We use taxonomic nomenclature according to DAVIS (1965-1985) and DAVIS et al. (1988) and BRumMitT and POWELl (1992).

\section{Materials and methods}

The research transect was $350 \mathrm{~m}$ long from sand dunes in the north-east to the water level below the salt marsh in the south-west (Fig. 1). Ground water samples were taken along the transect populated by the Ammophila arenaria subsp. arundinacea, Euphorbia paralias and Tamarix smrynensis communities (Fig. 2).

The cover of species (in \%) was estimated in 4 square meters $(2 \mathrm{~m} \times 2 \mathrm{~m}$ ) for each community according to the Braun-Blanquet scale, as proposed by VAN DER MAAREL (1979), using standard relevé methods (Mueller-Dumbois and EllENBERG, 1974). Groundwater samples were collected during July 2000 with a sample bottle after soil cores were with the 
use of a $7 \mathrm{~cm}$ diameter soil auger to a depth of $80 \mathrm{~cm}$ because mean root depth was about $80 \mathrm{~cm}$ for the studied species and four water samples were taken per community. The groundwater level was determined at the sampling time by sinking a hole and allowing the interstitial water to refill it. Groundwater samples were taken by boreholes which, as specified by Soil Survey Staff guidelines, were sunk at each sampling point (FAULKNER et al. 1989, SÁNCHEZ et al. 1998, ÁlvAREZ-Rogel et al. 2007, BORNMAN et al. 2008). All materials that might come in contact with the groundwater were rigorously cleaned with high purity reagents $\left(\mathrm{HCl}\right.$ and $\left.\mathrm{HNO}_{3}\right)$ and pure water (CREASEY and FLEGAL 1999).

Soil samples were taken from $4 \mathrm{~m} \times 4 \mathrm{~m}\left(16 \mathrm{~m}^{2}\right)$ plots with a soil auger and soil samples were air-dried, crushed and sieved using a $2 \mathrm{~mm}$ mesh. The groundwater samples were analysed for:

1) electrical conductivity using a Jenway analyser,

2) Acidity using a Beckman pH meter (BLACK 1968),

3) $\mathrm{K}^{+}, \mathrm{Ca}^{2+}$ and $\mathrm{Mg}^{2+}$ using a Perkin Elmer Atomic Absorption Spectrophotometer (HANLON 1998),

4) $\mathrm{SO}_{4}{ }^{2-}$ and $\mathrm{Cl}^{-}$(meq L ${ }^{-1}$ ) concentrations were determined by turbidimetric and gravimetric methods, respectively (ALLEN et al. 1986, KILINC et al. 2006),

5) exchangeable sodium ratio and sodium adsorption ratio were calculated according to HUSSEIN and RABENHORST (2001).

6) $\mathrm{HCO}_{3}{ }^{-}$concentration was determined by titration with sulphuric acid (ÁLVAREZ-ROGEL et al. 2006).

7) organic matter was determined according to the Walkley-Black method (KILINC et al. 2006).

To examine the relationships between plant communities and groundwater variables, canonical correspondence analysis (CCA) was applied (JoNGMAN et al. 1995) using ECOM version 1.33 (HENDERSON and SEABY 2001). The cover-abundance symbols of the Braun-Blanquet scale (r, +, 1, 2, 3, 4 and 5) were replaced by $1,2,3,4,5,7,8$ values according to VAN DER MAAREL (1979) and Focht and Pillar (2003).

\section{Results}

Chloride concentrations of groundwater and soil were rather high and sodium adsorption ratio and exchangeable sodium percentage values were also found to be high (Tab. 1). 
Pearson correlations between species and environment scores in canonical axis 1 and 2 were highly significant and explained $76 \%$ and $77 \%$ of the cumulative variance, respectively (Tab. 2). A Monte Carlo permutation test (999 permutations) confirmed the significance of the first two axes $(\mathrm{p}<0.001)$.

Tab. 2. Eigen values and species-groundwater chemical traits correlation coefficients.

\begin{tabular}{lcc}
\hline & Canonical Axis 1 & Canonical Axis 2 \\
\hline Canonical Eigenvalue & 0.422 & 0.379 \\
\% Variance explained & 5.877 & 5.284 \\
Cumulative \% variance & 5.877 & 11.16 \\
Pearson correlation species/environment scores & 0.756 & 0.774 \\
\hline
\end{tabular}

From the intra-set correlations of the soil factors with the first two axes of the CCA, electrical conductivity, exchangeable sodium ratio, water depth and organic matter concentration were the most significant parameters in axis 1 and all of these parameters were negatively correlated except for the soil organic matter concentration which was positively correlated. Along axis 2 , only soil $\mathrm{pH}$ was negatively correlated and none of the other parameters were significant (Tab. 3).

According to the CCA analysis $S$. prostrata was associated with exchangeable sodium ratio, while A. pseudalhagi and T. smrynensis were associated with water depth. J. littoralis, A. arenaria and E. paralias were associated with soil organic matter. Along axis $2 E$. paralias, A. arenaria and I. orientalis were associated with soil pH (Fig. 3).

The results from the detrended correspondence analysis (DCA) were similar to the results of the CCA analysis in that the species were arranged according to groundwater salinity along axis 1. Species grouped along a groundwater salinity gradient with $S$. prostrata grouping separately on the right of axis 1 followed by $J$. acutus and then rest of the species along the left of axis 1. DCA axis 2 represents the distance from the sea and sand-dune species like E. paralias, A. arenaria and J. littoralis grouped along the bottom of axis 2 (Fig. 4).

Tab. 3. Intraset correlation coefficients of soil and groundwater. Statistically significant correlations $(\mathrm{p}<0.05)$ are marked in bold.

\begin{tabular}{lcc}
\hline & Can. Axis 1 & Can. Axis 2 \\
\hline $\mathrm{pH}$ & 0.345 & $\mathbf{- 0 . 5 2 3}$ \\
$\mathrm{EC}$ & $\mathbf{- 0 . 8 1 7}$ & 0.131 \\
$\mathrm{ESR}$ & $\mathbf{- 0 . 6 4 4}$ & -0.145 \\
$\mathrm{OM}$ & $\mathbf{0 . 6 7 7}$ & -0.011 \\
$\mathrm{WD}$ & $\mathbf{- 0 . 5 7 9}$ & -0.394 \\
$\mathrm{SAR}$ & -0.151 & 0.039 \\
$\mathrm{~K}^{+}$ & -0.069 & 0.210 \\
$\mathrm{Ca}^{2+}$ & -0.005 & 0.424 \\
$\mathrm{Mg}^{2+}$ & 0.254 & 0.375 \\
$\mathrm{HCO}_{3}{ }^{-}$ & 0.055 & -0.282 \\
$\mathrm{Cl}^{-}$ & 0.308 & 0.236 \\
$\mathrm{SO}_{4}^{2-}$ & 0.001 & 0.245 \\
\hline
\end{tabular}


Kilinç M., G. Kutbay H., Yalçin E., Bilgin A., Avci K., Gencoglu Topaloglu S.

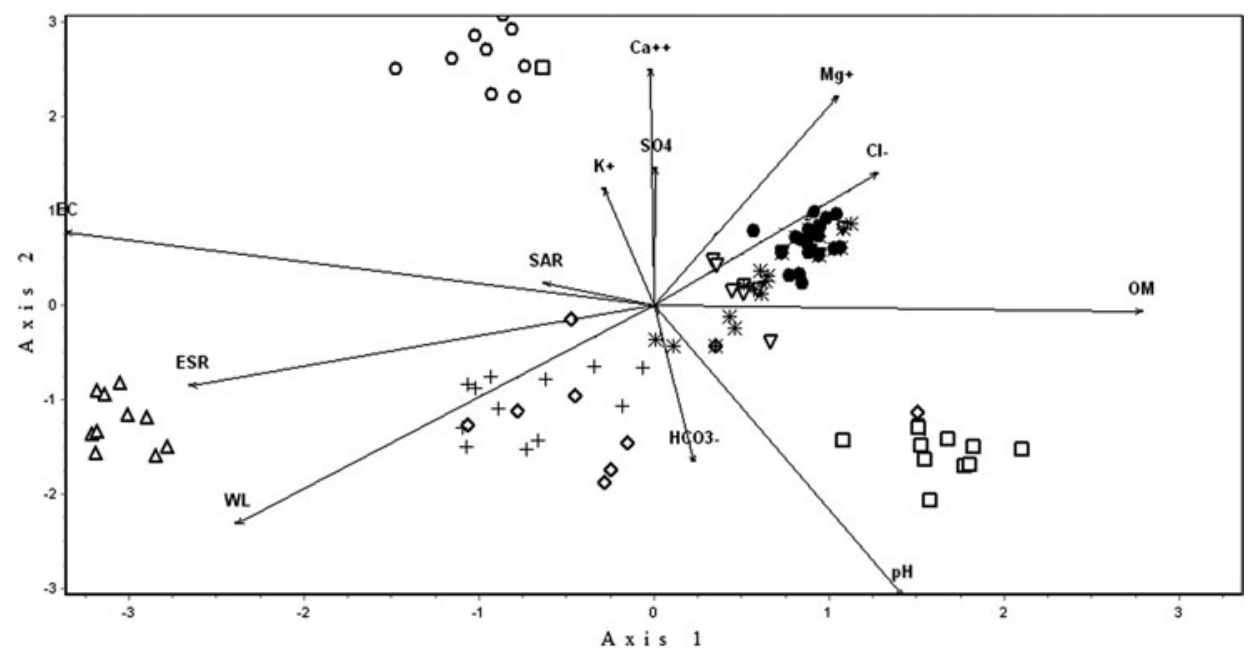

Fig. 3. The relationship among soil and groundwater traits and species by CCA. $\triangle$ Salicornia prostrata, $\diamond$ Tamarix smrynensis, $\bigcirc$ Juncus acutus, $\square$ Iris orientalis, + Alhagi pseudoalhagi, $\nabla$ Juncus littoralis, $\bullet$ Euphorbia paralias, * Ammophila arenaria

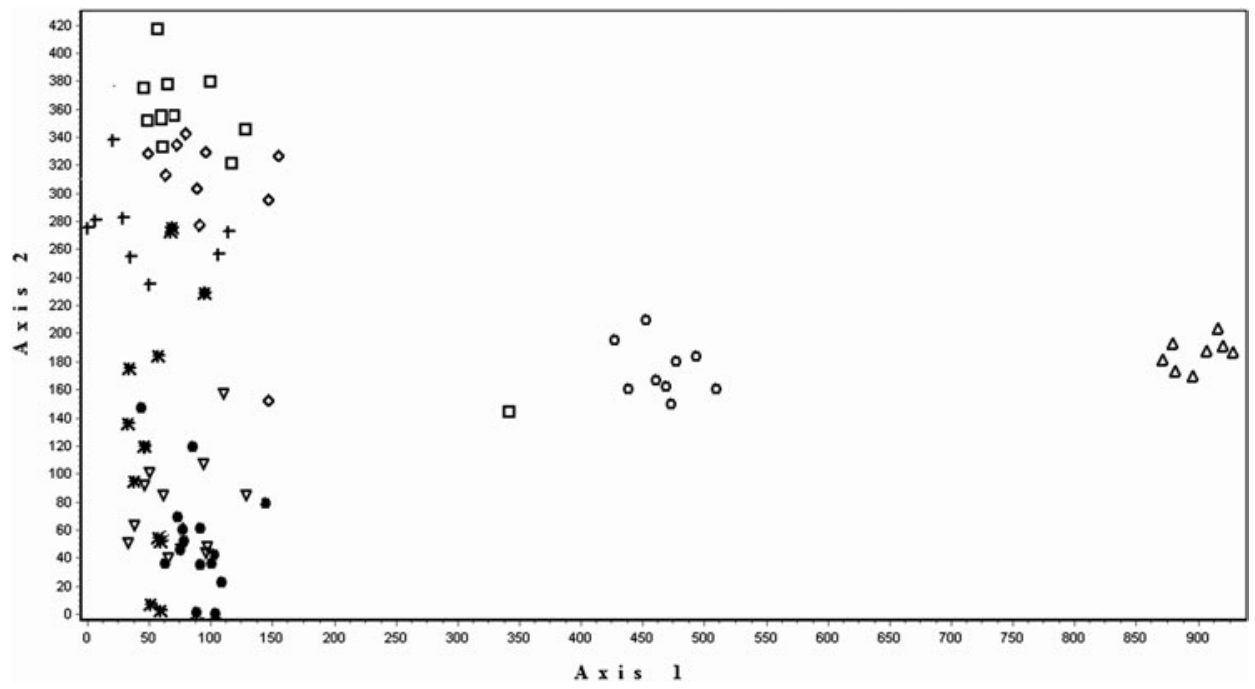

Fig. 4. The relationship among soil and groundwater traits and species by detrended correspondence analysis (DCA). $\Delta$ Salicornia prostrata, $\diamond$ Tamarix smrynensis, $\bigcirc$ Juncus acutus, $\square$ Iris orientalis, + Alhagi pseudoalhagi, $\nabla$ Juncus littoralis, $\bigcirc$ Euphorbia paralias, * Ammophila arenaria.

\section{Discussion}

Correlations between species and environmental scores indicated a strong association between communities and measured soil parameters, as has been already reported (JONGMAN et al. 1995, ABd EL-GHANi and AMER 2003). Salinity (electrical conductivity and ex- 
changeable sodium ratio), water depth and organic matter concentrations were found to be most significant environmental variables affecting salt marsh zonation. Groundwater salinity and depth (CANTERO et al. 1998b, MASHALY 2001, BORNMAN et al. 2002) and soil salinity (JI et al. 2009) have been identified as the most important factors in shaping vegetation patterns in other salt marsh ecosystems. Sodic soils are widespread in the study area because sodium adsorption ratio values $>13$ (AMEZKETA and DE LERSUNDI 2008)

Salicornia prostrata was associated with the most saline soils in the studied coastal salt marsh. This species forms monospecific stands along coastal salt marshes and inhabits salt-pan areas. These salt-pan areas are characterised by extreme conditions and Salicornia (Chenopodiaceae) species are regarded as fugitive species of these hypersaline bare patches and salt pans, because of their inability to compete with the dominant perennials (BERTNESS et al. 1992). It has been found that communities of halophytes were definitely better indicators of soil salinity than individual species and Salicornia occurred on extremely saline soils (PIERNIK 2003).

It is known that groundwater salinity is determined by tidal influences (SÁNCHEZ et al. 1998, Hussein and Rabenhorst 2001, ApAYdin et al. 2009, SAlama and BoKHARi 2009). Flooding has been classified as a determinant factor of vegetation patterns in coastal estuaries (JI et al. 2009). Salicornia prostrata subsp. prostrata is widely subject to flooding and closely associated with exchangeable sodium ratio and may therefore be used reliably to evaluate the impact of flooding in salt marshes.

Alhagi pseudalhagi and Tamarix smrynensis was closely associated with water depth and both species have been identified as groundwater indicating plants (ABD EL-GHANI 2000b; EL-BANA and AL-MATHNANi 2009). Soil organic matter is an important factor that regulates the distribution of Euphorbia paralias, Juncus littoralis and Ammophila arenaria (ABd El-GHANi and Amer 2003, OMER 2004, ZAHRAN and WiLlis 2008). Luxuriant growth of J.littoralis is associated with soil organic matter concentrations making individual clumpings, reaching a height of $100 \mathrm{~cm}$ (ABD EL-GHANI 2000a, EL-SHEIKH and ABBADI 2004). Juncus littoralis was also associated with $\mathrm{pH}$.

According to the DCA diagram the two different gradients are interpreted as salinity and distance from the sea. Salicornia prostrata occurred in the right of the DCA diagram and indicated the most saline soils. BURCHILL and KENKEL (1991) stated that the most saline areas in salt marshes are generally dominated by succulent annual species like Salicornia. Salicornia species are subject to regions characterized by downward flow, more frequent tidal recharge, and thus hypersaline soil conditions. These conditions permit the long-term persistence of fugitive species like Salicornia by maintaining a physically harsh hypersaline environment that is intolerable to neighbouring communities (THIBODEAU et al. 1998).

Juncus acutus and J. littoralis occurred in the middle and left of the diagram. Juncus L. species are classified as slow-growing plants with extensive below-ground reserves, and hence tend to respond slowly to changes in soil factors (PENNINGS et al. 2005, APAYDIN et al. 2009). Salinity is decreased to the left of the diagram. Coastal dune species (Ammophila arenaria, Euphorbia paralias) inhabit the lowest part, while Iris orientalis inhabits the upper part of the DCA diagram along the axis 2. I. orientalis occurred on inland dunes. These species usually adapted to less saline conditions as compared to Salicornia species (IHM et al. 2007). 
The importance of particular factors is likely to vary geographically in salt marshes. In particular, salinity stress probably plays a much more important role in mediating plant zonation patterns at lower latitudes (PENNINGS et al. 2005). Álvarez-Rogel et al. (2007) stated that salinity is more effective on zonation of communities than the vegetation and distance to the shoreline in a dune coastal salt marsh ecosystem. In the present study both factors (salinity and distance from the sea) were effective on plant zonation. The similarity between CCA and DCA suggests that there might be no other environmental variables missed in sampling (ABD EL-GHANI and AMER 2003).

Cisneros et al. (1999) found that vegetation modifies the speed of infiltration and the capillary flow of salt towards surface. It has been hypothesized that the heterogeneity of groundwater and soil traits and local topography are important determinants of plant species distribution and communities over a small geographic area (BORNMAN et al. 2004; EL-BANA and AL-MATHNANI 2009). The distribution of halophytic species has already been recognised to follow environmental gradients and the correlations between distribution and edaphic factors can be considered a first step towards understanding physical niches (ONAINDiA and AMEZEGA 1999, KHAZNADAR et al. 2009).

\section{References}

ABd El-GHANI, M. M., 2000a: Floristics and environmental relations in two extreme desert zones of western Egypt. Global Ecology and Biogeography 9, 499-516.

AbD El-Ghani, M. M., 2000b: Vegetation composition of Egyptian inland saltmarshes. Botanical Bulletin of Academia Sinica 41, 305-314.

Abd El-Ghani, M. M., Amer, W. A., 2003: Soil-vegetation relationships in a coastal desert plain of southern Sinai, Egypt. Journal of Arid Environments 55, 607-628.

AbDel-RAZiK, M. S., Ismail, A. M. A., 1990: Vegetation composition of a maritime salt marsh in Qatar in resltion to edaphic features. Journal of Vegetation Science 1, 85-88.

Allen, S. E., Grimshaw, H. M., Parkinson, J. A., Quarmby, C., Roberts, J. D., 1986: Chemical Analysis. In: Chapman, S. B. (ed.), Methods in Plant Ecology, 411-466. Blackwell Scientific Publications, Oxford.

AlPAR, B., 2009: Vulnerability of Turkish coasts to accelerated sea-level rise. Geomorphology 107, 58-63.

Álvarez-Rogel, J., Martínez-Sánchez, J. J., Blázguez, L. C., Semitiel, M. M., 2006: A Conceptual model of salt marsh plant distribution in coastal dunes of southeastern Spain. Wetlands 26, 703-717.

Álvarez-Rogel, J., Carrasco, L., Marín, C. M., MartíneZ-SÁnchez, J. J., 2007: Soils of a dune coastal salt marsh system in relation to groundwater level, micro-topography and vegetation under a semiarid Mediterranean climate in SE Spain. Catena 69, 111-121.

Amezketa, E., De Lersund, J. V., 2008: Soil classification and salinity mapping for determining restoration potential of cropped riparian areas. Land Degradation and Development 19, 153-164.

Apaydin, Z., Kutbay, H. G., Ozbucak, T., Yalcin, E., Bilgin, A, 2009: Relationships between vegetation zonation and edaphic factors in a salt-marsh community (Black Sea Coast). Polish Journal of Ecology 57, 99-112. 
Arslan, H., Guler, M., CemeK, B., Demir, Y., 2007: Assessment of groundwater quality in Bafra Plain for irrigation. Journal of Tekirdag Agricultural Faculty 4, 219-226.

Asri, Y., Ghorbanli, M., 1997: The halophilous vegetation of the Orumieh lake salt marshes NW Iran. Plant Ecology 132,155-170.

Bertness, M. D., Gough, L., Shumway, S. W, 1992: Salt tolerances and distribution of fugitive salt marsh plants. Ecology 73, 1842-1851.

BLACK, C. A., 1968: Soil-plant relationships. John Wiley and Sons, New York.

Bornman, T. G., AdAms, J. B., BATE, G. C., 2002: Freshwater requirements of a semi-arid supratidal and floodplain salt marsh. Estuaries 2, 1394-1405.

Bornman, T. G., Adams, J. B., Bate, G. C., 2004: The influence of floodplain geohydrology on the distribution of Sarcocornia pillansii in the Olifants Estuary on the West Coast, South Africa. Journal of Arid Environments 56, 603-625.

Bornman, T. G., Adams, J. B., Bate, G. C., 2008: Environmental factors controlling the vegetation zonation patterns and distribution of vegetation types in the Olifants Estuary, South Africa. South African Journal of Botany 74, 685-695.

Brummitt R.K., Powell, C. E., 1992: Authors of Plant Names. Royal Botanic Garden, Edinburgh.

Burchill, C. A., KenKel, N. C., 1991: Vegetation-environment relationships of an inland boreal salt pan. Canadian Journal of Botany 69, 722-732.

Cantero, J. J., Leon, R., Cisneros, J. M., CAntero, A., 1998a: Habitat structure and vegetation relationships in central Argentina salt marsh landscapes. Plant Ecology 137, 79-100.

Cantero, J. J., Cisneros, J. M., Zobel, M., Cantero, A., 1998b: Environmental relationships of vegetation patterns in salt marshes of central Argentina. Folia Geobotanica 33, $133-145$.

Chapman, V. J., 1974: Salt marshes and salt deserts of the world. J. Cramer, Lehre.

Cisneros, M., CANTERo, J. J., CANTERo, A., 1999: Vegetation, soil hydrophysical properties, and grazing relationships in saline-sodic soils of central Argentina. Canadian Journal of Soil Science 79, 399-409.

Creasey, C. L., Flegal, A. R., 1999: Elemental analyses of goundwater: demonstrated advantage of low-flow sampling and trace-metal clean techniques over standard techniques. Hydrogeology Journal 7, 161-167.

DAVIs, P. H., (ed.) 1965-1985: Flora of Turkey and the east Aegean islands, 1-9. Edinburgh University Press, Edinburgh.

Davis, P. H., Mill, R., TAN, K., (eds.) 1988: Flora of Turkey and the east Aegean islands, 10 (Supplement). Edinburgh University Press, Edinburgh.

Demir, Y., Ersahin, S., Guler, M., CemeK, B., Gunal, H., Arslan, H., 2009: Spatial variability of depth and salinity of groundwater under irrigated ustifluvents in the Middle Black Sea Region of Turkey. Environmental Monitoring and Assessment 158, 279-294.

El-Bana, M. I., Al-Mathnani, A, S., 2009: Vegetation-soil relationships in the Wadi Al-Hayat Area of the Libyan Sahara. Australian Journal of Basic and Applied Sciences 3, 740-747. 
Kilinç M., G. Kutbay H., Yalçin E., Bilgin A., Avci K., Gencoglu Topaloglu S.

El-SheIKH, M. A., ABADI, G. A., 2004: Biodiversity of plant communities in the Jal Az-Zor National Park, Kuwait. Kuwait Journal of Science and Engineering 31, 77-105.

Engin, A., Korkmaz H., 1990. The flora of the district between the body of the dam and Sahinkaya strait (Down Lake Area) and its close environment in the area of Bafra Altinkaya Dam Lake. Proceedings 10 National Biology Congress, Botany Session, Erzurum, 111-120.

Faulkner, S. P., Patrick, W. H., Gambrell, R. P., 1989: Field techniques for measuring wetland soil parameters. Soil Science Society of America Journal 53, 883-890.

Focht, T., Pillar, V. D., 2003: Spatial patterns and relations with site factors in campos grassland under grazing. Brazilian Journal of Biology 63, 23-436.

HANLON, E. A., 1998: Elemental determination by atomic absorption spectrophotometry. In: Y. P. KALRA (ed.), Handbook of reference methods for the plant analysis, 157-164. CRC Press, Boca Raton.

Henderson, P. A., Seaby, R. M. H., 2001: Environmental community analysis 1.33 version. Pisces Conservation Ltd., Lymington.

Hussein, A. H., RABENHORst, M. C., 2001: Tidal inundation of transgressive coastal areas: pedogenesis of salinization and alkalinization. Soil Science Society of American Journal 65, 536-544.

IHM, B S., LeE, J. S., KIM, J. W., KIM, J. H., 2007: Coastal plant and soil relationships along the southwestern coast of South Korea. Journal of Plant Biology 50, 331-335.

Ji, Y., ZHOU, G., NEw, T. 2009: Abiotic factors influencing the distribution of vegetation in coastal estuary of the Liaohe Delta, northeast China. Northeast China Estuaries and Coasts 32, 937-942.

Jongman, R. H., Terbraak, C. J. F., Tongeren, O. F. R., 1995: Data analysis in community and landscape ecology. Cambridge University Press. Cambridge.

Kennish, M. J. 2001: Coastal salt marsh systems in the U. S.: A review of antropogenic impacts. Journal of Coastal Research 17, 731-748.

KhaZnADAR, M., VogiatZakis, I. N., Griffiths, G. H., 2009: Land degradation and vegetation distribution in Chott El Beida wetland, Algeria. Journal of Arid Environments 73, 369-377.

Kilinc, M., Kutbay, H. G., Yalcin, E., Bilgin, A., 2006: Plant ecology and plant sociology practices. Palme Publications, Ankara.

Kutbay, H. G., Demir, M., 2001: The changes in nutrient contents of salt marsh species and the importance of edaphic physicochemical factors. Arab Gulf Journal of Scientific Research 19, 35-43.

Li Wei-Quiang, XiaO-Jing, L., Khan, M. A., Gul, B., 2008: Relationship between soil characteristics and halophytic vegetation in coastal regions of North China. Pakistan Journal of Botany 40, 1081-1090.

Mashaly, I. A., 2001: Contribution to the ecology of the deltaic Mediterranean coast, Egypt. Journal of Biological Sciences 1, 628-635.

Mitsch, W. J., Gosselink, J., 1993: Wetlands. Van Nostrand Reinhold, New York.

Mueller-Dumbois, D., EllenberG, H., 1974: Aims and methods of vegetation ecology. Wiley and Sons, New York. 
OMER, L. St. 2004: Small-scale resource heterogenity among halophytic plant species in an upper salt marsh community. Aquatic Botany 78, 337-448.

OnAindia, M., AmezegA, I., 1999: Natural regeneration in salt marshes of northern Spain. Annales Botanici Fennici 36, 59-66.

Pennings, S. C., Callaway, R. M., 1992: Salt marsh plant zonation: The relative importance of competition and physical factors. Ecology 73, 681-690.

Pennings, S. C., Grant, M. B., Bertness, M. D., 2005: Plant zonation in low-latitude salt marshes: disentangling the roles of flooding, salinity and competition. Journal of Ecology 93, 159-167.

PIERNIK, A., 2003: Inland halophilous vegetation as indicator of soil salinity. Basic and Applied Ecology 4, 525-536.

Salama, H. M. H, Bokhari, N., 2009: Relationship between plant cover type and soil properties on western coastal region, Saudi Arabia. Journal of Applied Sciences Research 5, 1040-1050.

SÁncheZ, J. M., Otero, X. L., IzCo, J., 1998: Relationships between vegetation and environmental characteristics in a salt-marsh system on the coast of Northwest Spain. Journal of Vegetation Science 136, 1-8.

Shaltout, K. H., Al-Sodany, Y. M., 2008: Vegetation analysis of Burullus Wetland: a Ramsar site in Egypt. Wetlands Ecology and Management 16, 421-439.

Thibodeau, P. M., Gardner, L. R., Reeves, H. W., 1998: The role of groundwater flow in controlling the spatial distribution of soil salinity and rooted macrophytes in a southeastern salt marsh, USA. Mangroves and Salt Marshes 2, 1-13.

VAN DER MAAREL, E., 1979: Transformation of cover-abundance values in phytosociology and its effects on community similarity. Vegetatio 39, 97-144.

Zahran, M. A., Willis, A. J., 2008: The Western Desert. The vegetation of Egypt. Springer.

ZHANG, J., 1996: Interactive effects of soil nutrients, moisture, and sand burial on the development, physiology, biomass and fitness of Cakile edentula. Annals of Botany 78, 591-598. 